\title{
Sanitary profile in mice and rat colonies in laboratory animal houses in Minas Gerais: I - Endo and ectoparasites
}

\author{
[Perfil sanitário de colônias de camundongos e ratos de biotérios de Minas Gerais: \\ I-Endo e ectoparasitos] \\ K.A. Bicalho ${ }^{1}$, F.T.M. Araújo ${ }^{1}$, R.S. Rocha ${ }^{2}$, O.S. Carvalho ${ }^{1}$ \\ ${ }^{1}$ Instituto René Rachou - Fiocruz \\ Av. Augusto de Lima 1715 \\ 30190-002 - Belo Horizonte, MG \\ ${ }^{2}$ Centro de Pesquisa Leônidas e Maria Deane - Fiocruz - Manaus, AM
}

\begin{abstract}
The sanitary conditions of 13 animal houses in nine public institutions in Minas Gerais, and the presence of endo and ectoparasites of mice and rats colonies kept in these facilities were evaluated. Data about barriers to prevent the transmission of diseases and a program of sanitary monitoring were obtained through a questionnaire and local visit. Parasitological methods were performed for diagnosing mite, lice, helminthes, and protozoa parasites in 344 mice and 111 rats. Data have shown that the majority of the animal houses had neither proper physical environment nor protection barriers to prevent the transmission of infections. Parasitological results have shown that only one animal house $(7.7 \%)$ had parasite free animals, whereas the others have presented infected animals and the prevalences of parasites in the mice colonies were: Myobia musculi (23.1\%); Myocoptes musculinus (38.5\%); Radfordia affinis (15.4\%); Syphacia obvelata (92.3\%); Aspiculuris tetraptera (23.1\%); Hymenolepis nana (15.4\%); Spironucleus muris (46.2\%); Giardia muris (46.2\%); Tritrichomonas muris (53.8\%); Trichomonas minuta $(61.5 \%)$; Hexamastix muris $(7.7 \%)$; and Entamoeba muris (84.6\%). As for the rat colonies, the prevalences were: Poliplax spinulosa (8.1\%); Syphacia muris (46.2\%); Trichosomoides crassicauda (28.6\%); Spironucleus muris (85.7\%); Tritrichomonas muris (85.7\%); Trichomonas minuta (85.7\%); Hexamastix muris (14.3\%) and Entamoeba muris (85.7\%).
\end{abstract}

Keywords: mice, rat, animal house, parasite, sanitary barrier

\section{RESUMO}

Avaliaram-se as condições sanitárias de 13 biotérios de nove instituições públicas do estado de Minas Gerais, bem como a presença de endo e ectoparasitos nos camundongos e ratos criados nesses biotérios. Os dados sobre barreiras contra infecções e sobre o programa de monitoramento sanitário dos animais foram obtidos por meio de um questionário e de visitas aos biotérios. Métodos parasitológicos foram utilizados para o diagnóstico de ácaros, piolhos, helmintos e protozoários em 344 camundongos e 111 ratos. A maioria dos biotérios não possuía espaços físicos adequados nem barreiras de proteção que pudessem impedir a transmissão de infecções. Os resultados parasitológicos mostraram que em apenas um biotério não foram encontrados animais parasitados. A prevalência de parasitos encontrados em camundongos nos outros biotérios foi: Myobia musculi (23,1\%), Myocoptes musculinus (38,5\%), Radfordia affinis (15,4\%), Syphacia obvelata $(92,3 \%)$, Aspiculuris tetraptera $(23,1 \%)$, Hymenolepis nana $(15,4 \%)$, Spironucleus muris $(46,2 \%)$, Giardia muris $(46,2 \%)$, Tritrichomonas muris $(53,8 \%)$, Trichomonas minuta $(61,5 \%)$, Hexamastix muris $(7,7 \%)$ e Entamoeba muris (84,6\%). E nas colonias de ratos foram encontrados: Poliplax spinulosa $(8,1 \%)$, Syphacia muris $(46,2 \%)$, Trichosomoides crassicauda $(28,6 \%)$, Spironucleus muris $(85,7 \%)$, Tritrichomonas muris $(85,7 \%)$, Trichomonas minuta $(85,7 \%)$, Hexamastix muris $(14,3 \%)$ e Entamoeba muris $(85,7 \%)$.

Palavras-chave: camundongo, rato, biotério, parasito, barreira sanitária

Recebido em 3 de janeiro de 2007

Aceito em 3 de setembro de 2007

E-mail: bkelly@cpqrr.fiocruz.br 


\section{INTRODUCTION}

The use of living laboratory animals as biological reagents has provided knowledge to better understand physiological and pathological processes in both man and other animals (Casebolt et al., 1988; Dillehay et al., 1990). Experimental results of research performed with living laboratory animals may be affected by physiological and immunological alterations caused by environmental conditions (Baker, 1998; Weisbroth et al., 1998). The presence of infectious agents in animal house colonies represents a severe problem for biomedical research once murine parasitic agents are described as the most frequent pathogens involved in immunological and metabolic alterations in the host (Pinto et al., 1994). Considering the use of laboratory living animals as models in experimental biomedical research, the animal houses are required to have barriermaintained systems, controlled environment conditions, and periodical genetic and sanitary monitoring. It is, of utmost importance to monitor different lineages for the presence of parasites, viruses, bacteria, fungi as well as their genetic constitution (Gilioli, 2003).

In Brazil, preliminary results have shown that most animal houses that supply mice and rats for biomedical research should have facilities and devices improved, including barrier-maintained systems to produce and maintain Specific Pathogen-Free (SPF) animals under controlled sanitary conditions (Gilioli, 2003). Gilioli et al. (1996, 2000) performed a parasitological survey as well as an investigation of the antibodies involved with murine infections caused by viruses and bacteria in 18 animal houses of Brazilian institutions. The authors reported that only one institution was able to provide SPF animals. On the other hand, animals with multiple infections caused by parasites, viruses and bacteria were commonly observed in most of animal house colonies under study. A similar infection pattern was reported for universities and institutes of the United States, Germany and Canada when infectious agents were investigated (Jacoby and Lindsey, 1997; Zenner and Regnault, 2000).

The present study aimed at adding new data on sanitary-hygienic conditions of animal houses of the state of Minas Gerais, Brazil, which provide biomedical research with mice and rats, and evaluating their health status by means of an assessment of ecto and endoparasite infections.

\section{MATERIALS AND METHODS}

Thirteen animal houses of nine public institutions that supply animals for teaching and research purposes were evaluated from November 2004 to April $2005^{*}$. Out of these public institutions of the state of Minas Gerais, eight were research/teaching institutions and one was an institution of research and production of pharmaceuticals, antiophidic serum and vaccines. All institutions had the purpose of breeding laboratory mice and rats of high sanitary quality to meet the demands of research/teaching, biological control of serum and feeding of ophidian. Data on barriers to prevent the transmission of diseases, on the program of sanitary monitoring and on human resources were obtained through a questionnaire and local visits that were carried out according to the date scheduled by the head of the animal house. The questionnaire had eleven questions and the main items assessed were: adequate facilities with clean area separate from the dirty one, central ventilation system with acclimatization, air filtration, temperature control, equipment like a double door autoclave, shelves, ventilated racks, isolators, cage washer, sanitizing showers, and adequate garment (uniform, cap, face shield, gloves, and shoe cover) for technicians to enter the clean area, frequency of disinfection of the animal house areas, disinfection and/or sterilization of materials and input (food, water, wood shavings, cages and uniforms), growing different species of animals in the same area, the presence of regular programs for sanitary monitoring of the colonies for virus, bacteria, parasites, and educational level of technicians, number and regular training.

The sample size was determined by the statistical formula: $\mathrm{A}=-\log \alpha / \log (1-\mathrm{P})$, being: $\mathrm{A}=$ number of animals to be assessed (sample size); $\mathrm{P}=$

\footnotetext{
*This project was submitted to the Ethics Committee for Animal Use of the Oswaldo Cruz Foundation (FIOCRUZ) and all the procedures involving the use of animals in the current study followed the Ethical Principles for the Use of Laboratory Animals, provided by the Brazilian School of Animal Experimentation (COBEA), and the Guide for the Care and Use of Laboratory Animals, by the National Research Council (National..., 2003).
} 
percentage of infected animals in the colony; and $\alpha=$ confidence limit. Considering that $\mathrm{P}=25 \%$ and $\alpha=0.05: \quad \mathrm{A}=12$ animals/breeding room/colony, i.e., $95 \%$ probability to detect at least one positive animal in the evaluated sample (Institute ..., 1976). Thus, 455 animals, randomly chosen (344 mice and 111 rats) from isogenic and heterogenic lineages of 13 mice and seven rat colonies, aged between four and 48 weeks were assessed. Mice and rats were transported separately in polycarbonate cages containing top filter media for laboratory animals and then kept in micro isolators up to the examination time, which was within 48 hours after the animal arrival. The animals were submitted to carbon dioxide anesthesia in an appropriate chamber, bled through the retroorbital plexus or cardiac puncture and, then, sacrificed through a deeper narcosis before necropsy.

Mites and lice were diagnosed through direct examination of the carcasses and identified through light microscopy of the fur collected from the cervical and dorsal regions as described by Weisbroth (1982) and Gilioli (2003). Specific identification was based on a microscopic morphological analysis after clarification with Hoyer liquid, at magnifications of 100x and 400x (Krantz, 1978; Owen, 1992). Eggs, larvae and adult helminthes were diagnosed by light microscopy, examining slices of the small and large intestines in samples of the lumen contents and in anal swab with scotch tape (Wescott, 1982; Owen, 1992). Coccid oocysts were searched according to the Sheater method (Sheater, 1923). Protozoan cysts and trophozoite were examined in small samples of the duodenal content and in the lumen of small intestine that were put on slides. A drop of $0,09 \%$ saline solution was added and the material was covered with cover glass and diagnosed by light microscopy, as described by Gilioli (2003). Specific identification was based on a microscopic morphological analysis at magnifications of 100x and 400x (Hsu, 1982; Owen, 1992). Whenever necessary, protozoan cysts were stained with iodine solution to enable their identification. Eggs and adult forms of the Trichosomoides crassicauda, endoparasite of the urinary bladder of rats were investigated. The specific endoparasite identification was made by microscopic morphological evaluation at magnifications of $100 \mathrm{x}$ and $400 \mathrm{x}$, as described by Owen (1992), Cornish et al. (1988), and Gilioli (2003).

\section{RESULTS}

Data analysis based on the questionnaire and local regular visits to the animal houses have showed that only one animal house $(7.7 \%)$ had a nearly complete set of sanitary barriers to supply and maintain mice under controlled sanitary conditions. Most of the animal houses (92.3\%) still maintain colonies under conventional conditions that are not planned to support SPF animals, since only one animal house $(7.7 \%)$ has appropriate facilities. Out of the 13 animal houses under study, three (23.0\%) showed a central ventilation system, three $(23.0 \%)$ had proper devices, including a double door autoclave, and seven (53.8\%) used vertical autoclaves to sterilize materials and supplies. Ventilated shelves and racks (ventilated isolator cages with filter-top) were used in eight (61.5\%) of the animal houses investigated, and isolators in one of them $(7.7 \%)$. Sanitizing showers to access the clean areas were present in one animal house $(7.7 \%)$. Cleaning-up in the breeding rooms was performed in $11(84.6 \%)$ of the animal houses and uniform sterilization in one $(7.7 \%)$ of them. Concerning disinfection/sterilization of materials and supplies, $13(100 \%)$ performed sterilization or disinfection of cages, four $(30.8 \%)$ sterilized food, and five (38.5\%) sterilized the water. The wood shaving was sterilized in nine $(69.2 \%)$ animal houses.

Breeding and maintenance of different species of mice and rats in the same breeding room was observed in five $(38.5 \%)$ of the animal houses that were: hamsters (Mesocricetus auratus); marmoset (Callithrix penicillata); rabbits (Oryctolagus cuniculis); gerbils (Meriones unguiculatus); calomys (Calomys sp); and guinea pigs (Cavia porcellus).

A regular program for sanitary monitoring of parasites, viruses and bacteria was carried out in one $(7.7 \%)$ animal house. Parasite monitoring was performed by three $(23.0 \%)$ of the animal houses and bacteria monitoring was performed by one $(7.7 \%)$ of them.

As for human resources to manage the animal houses, six $(46.2 \%)$ animal houses reported to have a specialized technical team and five 
(38.5\%) had sufficient personnel to perform the activities.

Results of the parasite survey, including ecto and endoparasites, in mice and rat colonies are shown in Tables 1 and 2, respectively. In 13 mice colonies, only one animal house (B) was negative for all parasites investigated, and $92.3 \%$ were positive for Syphacia obvelata, $61.5 \%$ for Trichomonas minuta, and $84.6 \%$ for Entamoeba muris (Table 1). In seven rat colonies, every animal house under study showed positive results for all parasites investigated, out of which $85.7 \%$ were positive for Syphacia muris and most protozoan species under study (Table 2).

Table 1. Occurrence of parasite in mice colonies in 13 animal houses investigated in the State of Minas Gerais

\begin{tabular}{|c|c|c|c|c|c|c|c|c|c|c|c|c|c|c|}
\hline \multicolumn{15}{|c|}{$\begin{array}{c}\text { Animal house } \\
\text { (Number of examined animals) }\end{array}$} \\
\hline & $\begin{array}{c}\text { A } \\
(48) \\
\end{array}$ & $\begin{array}{c}\mathrm{B} \\
(19) \\
\end{array}$ & $\begin{array}{c}\mathrm{C} \\
(12)\end{array}$ & $\begin{array}{c}\mathrm{D} \\
(13)\end{array}$ & $\begin{array}{c}E \\
(48) \\
\end{array}$ & $\begin{array}{c}F \\
(72) \\
\end{array}$ & $\begin{array}{c}\mathrm{G} \\
(36)\end{array}$ & $\begin{array}{c}\mathrm{H} \\
(12) \\
\end{array}$ & $\begin{array}{c}\mathrm{I} \\
(12) \\
\end{array}$ & $\begin{array}{c}\mathrm{J} \\
(12)\end{array}$ & $\begin{array}{c}\mathrm{K} \\
(12) \\
\end{array}$ & $\begin{array}{c}\mathrm{L} \\
(12) \\
\end{array}$ & $\begin{array}{c}\mathrm{M} \\
(36) \\
\end{array}$ & $\begin{array}{c}\text { Total of } \\
\text { positives }(\%)\end{array}$ \\
\hline \multicolumn{15}{|l|}{ Ectoparasite } \\
\hline Myobia musculi & 0 & 0 & 0 & 0 & 0 & 0 & 4 & 0 & 0 & 2 & 0 & 0 & 1 & 23.1 \\
\hline $\begin{array}{l}\text { Myocoptes } \\
\text { musculinus }\end{array}$ & 0 & 0 & 0 & 2 & 0 & 0 & 0 & 0 & 4 & 2 & 12 & 0 & 12 & 38.5 \\
\hline Radfordia affinis & 0 & 0 & 0 & 0 & 0 & 0 & 0 & 0 & 0 & 1 & 2 & 0 & 0 & 15.4 \\
\hline \multicolumn{15}{|l|}{ Helminth } \\
\hline Syphacia obvelata & 14 & 0 & 3 & 2 & 11 & 16 & 28 & 9 & 7 & 6 & 9 & 7 & 20 & 92.3 \\
\hline Aspiculuris tetraptera & 0 & 0 & 0 & 0 & 0 & 0 & 0 & 0 & 0 & 4 & 3 & 4 & 0 & 23.1 \\
\hline Hymenolepis nana & 0 & 0 & 0 & 0 & 6 & 0 & 0 & 0 & 0 & 3 & 0 & 0 & 0 & 15.4 \\
\hline \multicolumn{15}{|l|}{ Protozoan } \\
\hline Spironucleus muris & 0 & 0 & 2 & 0 & 0 & 5 & 0 & 0 & 2 & 1 & 10 & 0 & 5 & 46.2 \\
\hline Giardia muris & 1 & 0 & 0 & 0 & 1 & 6 & 0 & 3 & 5 & 0 & 0 & 0 & 2 & 46.2 \\
\hline Tritrichomonas muris & 0 & 0 & 0 & 0 & 29 & 0 & 23 & 0 & 12 & 12 & 12 & 11 & 30 & 53.8 \\
\hline Trichomonas minuta & 0 & 0 & 2 & 0 & 0 & 2 & 24 & 0 & 12 & 12 & 12 & 11 & 30 & 61.5 \\
\hline Hexamastix muris & 2 & 0 & 0 & 0 & 0 & 0 & 0 & 0 & 0 & 0 & 0 & 0 & 0 & 7.7 \\
\hline Entamoeba muris & 6 & 0 & 4 & 0 & 9 & 2 & 13 & 2 & 4 & 1 & 4 & 1 & 10 & 84.6 \\
\hline
\end{tabular}

Table 2. Occurrence of parasite in rat colonies in seven animal houses investigated in the State of Minas Gerais

\begin{tabular}{|c|c|c|c|c|c|c|c|c|}
\hline \multicolumn{9}{|c|}{$\begin{array}{c}\text { Animal house } \\
\text { (Number of examined animals) }\end{array}$} \\
\hline & $\begin{array}{c}\text { A } \\
(36)\end{array}$ & $\begin{array}{c}\mathrm{G} \\
(24)\end{array}$ & $\begin{array}{c}\mathrm{H} \\
(7)\end{array}$ & $\begin{array}{c}\text { I } \\
(12)\end{array}$ & $\begin{array}{c}J \\
(12)\end{array}$ & $\begin{array}{c}\mathrm{K} \\
(12)\end{array}$ & $\begin{array}{l}\mathrm{M} \\
(8)\end{array}$ & $\begin{array}{c}\text { Total of positives } \\
(\%)\end{array}$ \\
\hline \multicolumn{9}{|l|}{ Ectoparasite } \\
\hline Poliplax spinulosa & 0 & 0 & 0 & 9 & 0 & 0 & 0 & 14.3 \\
\hline \multicolumn{9}{|l|}{ Helminths } \\
\hline Syphacia muris & 27 & 0 & 7 & 11 & 11 & 10 & 7 & 85.7 \\
\hline Trichosomoides crassicauda & 1 & 0 & 0 & 0 & 0 & 0 & 3 & 28.6 \\
\hline \multicolumn{9}{|l|}{ Protozoan } \\
\hline Spironucleus muris & 27 & 3 & 0 & 2 & 4 & 7 & 8 & 85.7 \\
\hline Tritrichomonas muris & 36 & 24 & 0 & 11 & 12 & 10 & 7 & 85.7 \\
\hline Trichomonas minuta & 36 & 16 & 0 & 12 & 11 & 11 & 8 & 85.7 \\
\hline Hexamastix muris & 1 & 0 & 0 & 0 & 0 & 0 & 0 & 14.3 \\
\hline Entamoeba muris & 20 & 8 & 0 & 6 & 6 & 3 & 5 & 85.7 \\
\hline
\end{tabular}

\section{DISCUSSION}

The animal house B has succeeded in breeding laboratory animals with defined sanitary quality due to its aim at growing germ-free animals. In order to reach this goal, the animals were kept in positive pressure isolators and following strict sterilization procedures for all material and supplies (cages, water bottles, food, wood shaving) used for handling the animals, what reinforces the idea that the stricter the sanitary barriers, the smaller the probability of detecting pathogens in the colonies (Gilioli, 2003). Unlike animal house $\mathrm{B}$, in most of the other animal houses $(92.3 \%)$, the majority of animals were kept on shelves in open cages and there was no efficient system of protection barriers for SPF animals husbandry. Besides, the absence of proper facilities for breeding and keeping the animals shows the need of planning by experts in 
the area so that the facilities meet the requirements for each species and enable microbiological, parasitological, and environmental control for husbandry of high quality standard laboratory animals (Andrade et al., 2002).

Double door autoclave is the main piece of equipment used for sterilization in the animal house, and the results of this study showed that 10 animal houses did not have it, what may jeopardize material and supplies sterilization processes. Regarding water quality, it must be of potable standard, it must be sterilized before being given to the animals and frequently changed in order to prevent circulation of harmful water born substances and pathogenic agents mainly protozoa (De Lucca et al., 1996). The fact that eight animal houses did not sterilize the water or did not frequently change it may explain the large number of animal houses that were positive for protozoa, especially Entamoeba muris $(>80 \%)$.

The results showed that nine animal houses sterilized wood shaving used for animal bedding. This supply is part of the micro environment of the animals, so it may be one of the main sources of contamination in the colonies, therefore, it should always be sterilized to prevent the outbreak of diseases (Andrade et al., 2002).

Although five animal houses in different institutions had been gradually substituting the use of open cages for ventilated isolator cages with filter-top (micro isolators), the animals were still found infected. This fact indicates that other control measures such as sanitizing showers, disinfection/sterilization of materials, supplies, breeding areas and their re-colonization with high sanitary quality animals are needed to provide SPF animals.

The lack of facilities, devices, expertise and rigorous sanitary barriers associated with poor management in animal houses enable dissemination of pathogenic agents detected within and among colonies maintained in breeding rooms, physically separated, but handled by the same personnel (Homberger and Thomann, 1994; Gilioli, 2003).

Furthermore, high parasite prevalence was expected in the animal houses investigated due to the presence of different species of mice and rats in the same breeding room/area. It is preconized that animals of different species are physically separate to avoid interspecific transmission of diseases, anxiety, and possible behavioral or physiological alterations caused by conflicts among species. If it is not possible to separate the species, mice and rats may be grown in the same area due to their similar pathogenic profile and compatible behavior (National..., 2003). Nowadays, transference of biological material and genetically modified mice among different institutions, with no regular quarantine sanitary programs and caesarian rederivation of the animals, has also enabled dissemination of pathogenic agents among colonies (Nicklas and Weiss, 2000; Mahabir et al., 2004).

Regarding the category of the parasites investigated, five animal houses were positive for ectoparasites, helminthes and protozoa $(\mathrm{G}, \mathrm{I}$, $\mathrm{J}, \mathrm{K}$ e M), and seven animal houses were positive for helminthes and protozoa (A, C, D, E, F, H e $\mathrm{L})$. Regarding the ectoparasites searched, mice colonies showed higher rate of infection by Myocoptes musculinus, what confirmed high prevalence of this ectoparasite in conventional colonies worldwide. The ectoparaiste Poliplax spinulosa was found in one rat colony. This species of louse has been reported as biological vector of Haemobartonella muris and Rickettsia tythi and as a likely vector of Trypanosoma lewisi (Gilioli, 2003). The presence of ectoparasites in mice and rat colonies indicates a faulty handling and absence of sanitary barriers (Jacoby and Lindsey, 1997).

Results of the presence of Syphacia obvelata and Syphacia muris prove the high prevalence and worldwide spread of these helminthes in colonies kept under conventional conditions. Such fact may also be due to the nematode short life cycle that can induce infection in a large number of animals within short periods of time (Zenner and Regnault, 2000; Bazzano et al., 2002).

Cestoid Hymenolepis nana, a commonly found parasite in mice and rat colonies kept under conventional conditions was detected in two animal houses $(15.4 \%)$. It is important to remark that this parasite has a zoonotic potential and its characteristics of autoinfection and direct cycle contribute to maintain the high prevalence of animal infection in the colonies (Fox et al., 
1984). Therefore, infected animals are not recommended for research use due to the risk of transmission among technicians and investigators who handle the colonies. Besides, this parasite may affect experimental results of investigations involving gastrointestinal, hematological, immunological and nutritional issues (Potkay, 1994; Gilioli, 2003).

Yet, regarding the helminthes searched, two animal houses (A e M) were positive for Trichosomoides crassicauda in rat colonies. Infection by this pathogen has been associated to eosinophilia, the presence of globular leucocytes in the urinary tract, vesicles and tumors. Besides, migration of larvae to lungs may increase incidence of chronic respiratory diseases, what make animals improper for researching (Zubaidy and Majeed, 1981).

Trichomonas muris, Tritrichomonas minuta, Hexamastix muris and Entamoeba muris have been considered commensal agents not related to alterations of the animal health or interferences in experimental results so far. On the other hand, Spironucleus muris and Giardia muris were the protozoa of high clinical importance detected in this study. In mice colonies, three animal houses were positive for $S$. muris (C, J e K), three were positive for $G$. muris (A, E e H), and three were positive for two protozoa (F, I e M). Whereas in rat colonies, except for animal house $\mathrm{H}$, all of them were positive for $S$. muris. Mild infections by these pathogens in immunocompetent animals are usually symptomless and subclinical. In more severe infections, some clinical signs (diarrhea, creeps, lethargy, weight loss, rachitis) may be observed (Gilioli, 2003).

Infected animals are not indicated for experimental use due to a possible negative influence on experimental results. Although most of these infections are subclinical, they are relevant as they are able to affect the animal physiology, leading to changes in immunological, histological, nutritional, biochemical, and hematological parameters, besides affecting susceptibility to other infectious agents (Pinto et al., 1994; Bazzano et al., 2002).

The results of the current study indicate the need of massive investment on laboratory animal science and technology (physical environment, equipment, human resources qualification, implementation of strict sanitary barriers and sanitary monitoring) in the animal houses of the state targeting for the high quality of living laboratory animals for biomedical research. Furthermore, quarantine programs are also needed so that new animals or biological materials can be isolated up to the moment their health status may be assessed and then introduced into the sanitary-controlled colonies (Rehg and Toth, 1998; Gilioli, 2003).

\section{ACKNOWLEDGEMENTS}

We thank Dr. Rovilson Gilioli, head of the Laboratório de Controle de Qualidade Animal do Centro Multidisciplinar de Investigação Biológica (CEMIB/Unicamp), for teaching parasitological diagnosis in laboratory rodents, and the Coordinators of the Animal Houses of the state of Minas Gerais for kindly providing animals for the present study.

\section{REFERENCES}

ANDRADE, A.; PINTO, S.C.; OLIVEIRA, R.S. (Org). Animais de laboratório: Criação e Experimentação. Rio de Janeiro: Fiocruz, 2002. $388 \mathrm{p}$.

BAKER, D.G. Natural pathogens of laboratory mice, rats and rabbits and their effects on research. Clin. Microbiol. Rev., v.11, p.231-266, 1998.

BAZZANO, T.; RESTEL, T.I.; PINTO, R.M. et al. Patterns of infection with the nematodes Syphacia obvelata and Aspiculuris tetraptera in conventionally maintained laboratory mice. Mem. Inst. Oswaldo Cruz, v.97, p.847-853, 2002.

CASEBOLT, D.B.; LINDSEY, J.R.; CASELL, G.H. Prevalence rates of infectious agents among commercial breeding populations of rats and mice. Lab. Anim. Sci., v.38, p.327-329, 1988.

CORNISH, J.; VANDERWEE, M.A.; FINDON, G. et al. Reliable diagnosis of Trichosomoides crassicauda in the urinary bladder of the rat. Lab. Anim. v.22, p.162-165, 1988.

DE LUCCA, R.R.; ALEXANDRE, S.R.; MARQUES, T. et al. Manual para técnicos em bioterismo. 2.ed. São Paulo: COBEA, FINEP, 1996. p.3-10.

DILLEHAY, D.L.; LEHNER, N.D.M.; HUERKAMP, M.J. The effectiveness of microisolator cage system and sentinel mice for 
controlling and detecting MHV and Sendai virus infection. Lab. Anim. Sci., v.40, p.367-370, 1990.

FOX, J.G.; NEWCOMER, C.E.; ROZMIAREK, H. Selected zoonoses and other health hazards. In: FOX, J.G.; COHEN, B.J.; LOEW, F.M. (Eds). Laboratory animal medicine. New York: Academic, 1984. p.613-648.

GILIOLI, R.; ANDRADE, L.A.G.; PASSOS, L.A.C. et al. Parasite survey in mouse and rat colonies of Brazilian laboratory animal houses kept under differents sanitary barrier conditions. Arq. Bras. Med. Vet. Zootec., v.52, p.33-37, 2000.

GILIOLI, R.; SAKURADA, J.K.; ANDRADE, L.A.G. et al. Virus infection in rat and mouse colonies reared in Brazilian animal facilities. $L a b$. Anim. Sci., v.46, p.582-584, 1996.

GILIOLI, R. Avaliação do perfil sanitário de colônias de camundongos e de ratos em biotérios brasileiros: ocorrência de bactérias, parasitas e vírus murinos. 2003. 138f. Tese (Doutorado) Instituto de Biologia, Universidade Estadual de Campinas, Campinas, SP.

HOMBERGER, F.R.; THOMANN, P.E. Transmission of murine viruses and mycoplasma in laboratory mouse colonies with respect to housing conditions. Lab. Anim., v.28, p.113-120, 1994.

HSU, C-K. Protozoa. In: FOSTER, H.L.; SMALL.J.D; FOX, J.G (Eds). The Mouse in biomedical research: Diseases. New York: Academic, 1982. v.2 . p.358-372.

INSTITUTE for Laboratory Animal Resources. Long term holding of laboratory rodents. A report of the Committee on Long-term Holding of laboratory rodents. ILAR News, v.19, p.1-25, 1976.

JACOBY, R.O.; LINDSEY, J.R. Health care for research animals is essencial and affordable. FASEB J., v.11, p.609-614, 1997.

KRANTZ, G.W. Examination and mounting techniques. In: CERVALLIS (Ed). Manual of acarology. 2.ed. Cervallis: Oregon State University, 1978.

MAHABIR, E.; JACOBSEN, K.; BRIELMEIR, M. et al. Mouse antibody production test: can we do without it? J. Virol. Meth., v.120, p.239-245, 2004.

NATIONAL Research Council. Institute of Laboratory Animal Resources. Comission on life sciences. Manual sobre Cuidados e Usos de Animais de Laboratório. Goiânia: AAALAC/COBEA, 2003. 162p.

NICKLAS, W.; WEISS, J. Survey of embryonic stem cells for murine infective agents. Comp. Med., v.50, p.410-411, 2000.

OWEN, D.G. (Ed). Parasites of laboratory animals. Laboratory Animals Handbooks., n.12. London: Royal Society of Medicine Services Limited,1992. 170p.

PINTO, R.M.; VICENTE, J.J.; NORONHA, D. et al. Helminth parasites of conventionally maintained laboratory mice. Mem. Inst. Oswaldo Cruz, v.89, p.33-40, 1994.

POTKAY, S. Hymenolepis ssp. In: WAGGIE, K.; KAGIYAMA, N.; ALLEN, A.M. et al. (Eds). Manual of microbiologic monitoring of laboratory animals. Bethesda: National Institute of Health, 1994. p.191-195.

REHG, J.E.; TOTH, L.A. Rodent quarantine programs: purpose, principles and practice. $L a b$. Anim. Sci., v.48, p.438-477, 1998.

SHEATER, L. The detection of intestinal protozoa and mange parasites by flotation technique. $J$. Comp. Pathol., v.36, p.266-275, 1923.

WEISBROTH, S.H.; PETERS, R.; RILEY, L.K. et al. Microbiological assessment of laboratory rats and mice. ILAR J., v.39, p.1-28, 1998.

WEISBROTH, S.H. Arthropods. In: FOSTER, H.L.; SMALL, J.D.; FOX, J.G. (Eds). The mouse in biomedical research: diseases. New York: Academic, 1982. p.385-401.

WESCOTT, R.B. Helmints. In: FOSTER, H.L.; SMALL, J.D.; FOX, J.G. (Eds). The mouse in biomedical research: diseases. New York: Academic, 1982. v.2. p.372-384.

ZENNER, L.; REGNAULT, J.P. Ten-year long monitoring of laboratory mouse and rat colonies in French facilities: a retrospective study. Lab. Anim., v.34, p.76-83, 2000.

ZUBAIDY, A.J.; MAJEED, S.K. Pathology of the nematode Trichosomoides crassicauda in the urinary bladder of laboratory rats. Lab Anim., v.15, p.381-384, 1981. 